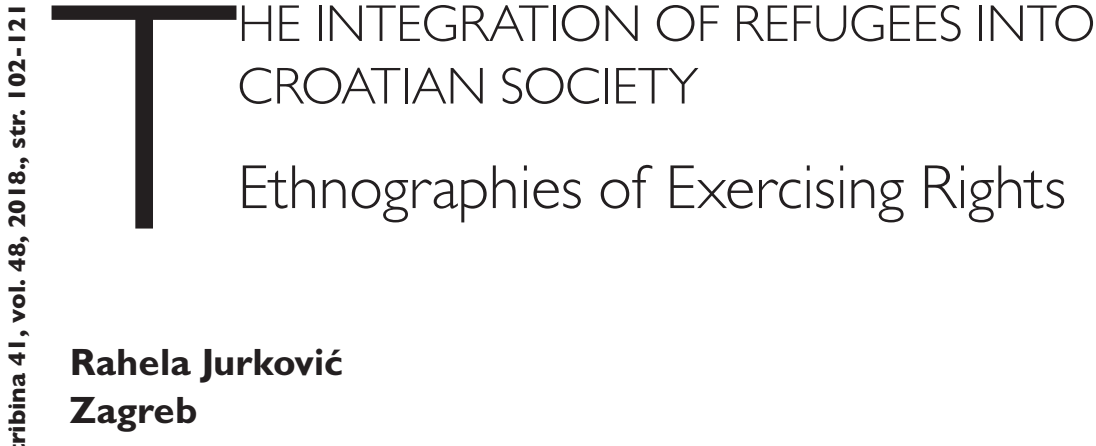

Refugees who are beneficiaries of international protection in Croatia are granted rights, the implementation of which is discussed in this article, based on qualitative research methods conducted between February 2015 and September 2017. The article discusses how these granted rights are exercised by individuals - persons who have been granted asylum in Croatia. The research is based on an ethnography of the particular, involving participant observation and open and semi-structured interviews with refugees and representatives of institutions and organizations involved in integration. The main Croatian legislative act valid during the research period was partially implemented. Its implementation was the most problematic in an area that refugees consider as essential for integration: the provision of state-supported Croatian language courses. Other problematic areas for exercising rights were access to healthcare and to the education system. The article also compares the research findings with the results of migrants' and refugee studies completed in (mostly) Western European countries. Besides similarities with such studies, this research acknowledges the importance of a local context for integration and introduces a new, existential dimension of integration that proved to be crucial for the successful integration of refugees in Croatia.

Keywords: refugees, international protection, asylum, subsidiary protection, integration

\title{
Introduction
}

The refugees to whom I refer in this article are the beneficiaries of international protection in Croatia - i.e. persons who have been granted asylum or subsidiary protection in the Republic of Croatia. While Croatia signed the Convention Relating to the Status of Refugees in 1992, ${ }^{1}$ known as the 1951 (or Geneva) Convention, it granted international protection on the basis of the Convention for the first time in 2006, due to the "influence" of the European Union (cf. Lalić Novak 2013), i.e. the European Commission. ${ }^{2}$ Such influence was triggered by the obligatory harmonization of Croatian legislation with that of the European Union (EU) during the process of Croatia's EU accession. In line with the Geneva Convention, the currently valid Croatian Act on International and Temporary Protection (Zakon o medunarodnoj $i$

${ }^{1}$ Source: https://treaties.un.org/doc/Treaties/1954/04/19540422\%2000-23\%20AM/Ch_V_2p.pdf (accessed 16. 3.2018).

${ }^{2}$ Although during the 1990s the Republic of Croatia experienced a significant inflow of refugees, connected to the war in Croatia and other countries of the former Yugoslavia, the scope of the research presented in this paper is not related to that period nor the integration of the 1990 s refugees into Croatia. 
privremenoj zaštiti) grants asylum to persons "who are outside the country of their nationality or habitual residence and have a well-founded fear of persecution owing to their race, religion, nationality, affiliation to a certain social group or political opinion, as a result of which they are not able or do not wish to accept the protection of that country" (Article 20 of the Act). Subsidiary protection is granted "to an applicant who does not meet the conditions to be granted asylum [...] if justified reasons exist to indicate that if returned to his or her country of origin he or she would face a real risk of suffering serious harm ${ }^{3}$ and who is unable, or, owing to such risk, is unwilling to avail himself or herself of the protection of that country" (Article 21 of the Act).

The history of Croatia's asylum seeking and asylum granting processes and different aspects of these processes have been discussed by several authors (e.g. ŽuparićIljić 2013; Baričević 2014). In this paper I focus on the integration of persons who are beneficiaries of international protection in Croatia. From 2006 to the end of 2017 there were 485 such persons; 337 men and 148 women. The largest number of them (211) received protection in 2017. International protection can be equated to the rights to which these persons are entitled from the day they receive the decision approving them international protection, issued by the Ministry of the Interior of the Republic of Croatia. This article discusses how the granted rights were exercised by these individuals, i.e. by the persons who received asylum in Croatia. It will first explain the methodological approach taken, followed by the relevant theoretical framework and explanation of the rights granted to the beneficiaries of international protection. The core of the study that follows presents the results of the research: an ethnography of how refugees exercise their rights in Croatia. The findings are then reflected on in light of Foucault's thinking on biopolitics and governmentality, and, finally, concluding remarks are presented.

\section{Methodological approach}

From February 2015 to September 2017, I conducted the qualitative research that formed the foundation of my doctoral thesis defended in January 2018, 5 on which this article is based. The research was influenced by the idea of an "ethnography of the particular" (Abu-Lughod 1991), and the two reasons Abu-Lughod gave in order to explain why anthropologists should be wary of generalization. The first reason was that, as a part of a professional discourse of "objectivity" and expertise, generalization was inevitably a language of power; "the language of those who seem to stand

\footnotetext{
${ }^{3}$ Whereas "serious harm assumes the threat of death by penalty or execution, torture, inhuman or degrading treatment or punishment and serious and individual threat to the life of the civil population due to arbitrary generalised violence in situations of international or internal armed conflicts" (Article 21 of the Act).

${ }^{4}$ Source: http://stari.mup.hr/main.aspx?id=188055 (accessed 16. 3. 2018).

${ }^{5}$ The thesis entitled Integration of Persons under International Protection in Croatian Society (Jurković 2018) was defended on 31 January 2018, with the grade Summa cum laude.
} 
apart from and outside of what they are describing" (ibid.: 474), which is a position I did not want to take. The second reason that Abu-Lughod gave as to why generalization should be avoided stems from "the effects of homogeneity, coherence, and timelessness it tends to produce" (ibid.: 475). At the start of my research, there were too many other people's voices circulating concerning who the refugees were, what they needed, and very often the refugees were "regarded as simply unreliable informants", as Malkki (1996: 384) rightly pointed out. As regards their integration into Croatian society, I often heard certain statements that, after having completed the research, I can qualify as generalizations that were - in the cases I researched - untrue; these included statements such as: "they want to leave Croatia", "they do not want to learn the Croatian language", "they are not trustworthy". My main concern was to hear directly from persons who had gained international protection in Croatia how they exercised their rights, as this significantly influenced how they started to integrate into Croatian society. During the research period, spanning over more than two years, I conducted semi-structured interviews with eleven adult persons who had received protection, and more open interviews with persons who had received or were seeking protection, as well as with representatives of the organizations and institutions who were involved in their integration into society. All the refugees involved in the research lived in Zagreb, and the great majority of them were men. While the persons who were granted asylum in Croatia are predominantly men (as illustrated by the previously presented figures), including women as informants turned out to be difficult (some of the women simply did not reply to my request to conduct an interview, and in general women were less visible as refugees than men - for instance at events related to the topic of refugees). As my research on integration and exercising of their rights did not involve specific concerns as regards a gender dimension, I did not research any further the issue of the reluctance of women in testifying about their experiences and participating in interviews, and this topic remains open for further research.

Besides semi-structured interviews, my research involved the method of participant observation (Potkonjak 2014: 68), where my participation involved assisting my informants in solving problems that concerned the exercising of the rights they had gained. For instance, on behalf of one of my informants I wrote a letter in Croatian to an institution to facilitate his access to a right he possessed, while with another informant I went to an institution to fill in a request in Croatian, in order to facilitate access to another right this informant possessed. This was possible as my ethnographic field research involved not only entering into a social setting but also getting to know the people involved in it and being immersed in their worlds "in order to grasp what they experience as meaningful and important" (Emerson et al. 1995: 2). Some of my informants were persons I interviewed on one or several occasions, while I followed others over a period of several months, or during the whole period of my research. The informants had different educational backgrounds (from having completed elementary school to having graduated from university), different occupations (cook, sportsman, musician, professional truck driver, lawyer, house- 
wife, activist), different ages (from 19 to 42) and different situations as concerns their living in Croatia (as single persons, as a family, or in a shelter for homeless people). Their countries of origin were: Afghanistan, Congo, Nigeria, Pakistan, Senegal, Syria and Somalia. For none of them, except for one Syrian family, was Croatia a destination country, and even the Syrian family came to Croatia within the framework of the EU relocation programme, which was "distributing" asylum seekers from Greece to other EU countries. Before going into the details of how the persons who gained international protection in Croatia exercised the rights that such protection granted them, I will first outline the work of scholars who influenced my research into the integration of refugees into Croatian society, and how their results correlate with the results of the research I conducted.

\section{Integration: theoretical framework}

A single definition or theory of integration acceptable to everyone, according to many scholars, simply does not exist (cf. Castles et al. 2002). However, many scholars have adopted - for the sake of their particular research - working definitions of integration. For instance, Penninx defined integration as "the process of becoming an accepted part of society" (2007: 10), which he described as being an elementary definition of integration. Ager and Strang, who conducted a study that resulted in what they called an "integration framework" consisting of the key factors that contribute to the process of the integration of refugees in the United Kingdom (UK), tentatively defined that "elusive term", as they called it (2004: 5), in the following way:

An individual or group is integrated within a society when they: achieve public outcomes within employment, housing, education, health etc. which are equivalent to those achieved within the wider host communities; are socially connected with members of a (national, ethnic, cultural, religious or other) community with which they identify, with members of other communities and with relevant services and functions of the state; and have sufficient linguistic competence and cultural knowledge, and a sufficient sense of security and stability, to confidently engage in that society in a manner consistent with shared notions of nationhood and citizenship. (ibid.)

They rightly remarked, while further explaining that this definition is more a goal to be achieved than a reality for many, that the cited "degree of involvement" in society is "not achieved by many people within the UK, regardless of their immigration status" (ibid.: 6).

Scholars have also discussed dimensions of integration and areas that are important for the integration of refugees. As concerns integration's dimensions, Esser (2001 op. cit. Penninx and Garcés-Mascareñas 2016: 13) identified four dimen- 
sions: culturation (similar to socialisation), placement (position in society), interaction (social relations and networks), and identification (belonging). Heckmann and Schnapper (2003 op. cit. Penninx and Garcés-Mascareñas 2016: 13) distinguished between structural, cultural, interactive and identificational integration, while Penninx (2007) referred to three dimensions of integration: the legal/political, the socio-economic, and the cultural/religious one. Furthermore, Penninx argued that there are three levels relevant for integration and its measurement: the individual (migrant's) level, the collective level of the immigrant group, and the level of institutions. On that third level he makes a distinction between two kinds of institutions important for the integration of migrants: the general public institutions of the receiving societies, and specific institutions of and for immigrant groups (Penninx 2007: 11-12). This article compares and interrelates two levels at which the integration of refugees occurs: the individual level, and the level of the general public institutions of the host society.

Ager and Strang's $(2004,2008)$ earlier mentioned "integration framework" has been used by other scholars (e.g. Pittaway et al. 2009; Valenta and Bunar 2010; Kirkwood et al. 2014; Smith 2015) in their empirical studies on the integration of refugees. That framework consists of ten key domains that Ager and Strang found to assume a central importance in the integration of refugees. These ten domains have been grouped around four indicators of integration: means and markers (employment, housing, education, and health), social connections (social bridges, social bonds, and social links), facilitators (language \& cultural knowledge, and safety \& stability), and foundations (rights \& citizenship). Ager and Strang (2004: 5) suggested that there was no hierarchy between the domains important to integration nor that "any domain was more important than any other". However, based on the ethnographies of the particular used in my research, my conclusion is that, on the contrary, some domains were more important than others. First and foremost, knowledge of the Croatian language was mentioned by all my informants as a top priority for their integration into Croatian society, and that it was an area that basically influences all other areas of integration.

As a final note to this section, I will briefly present what my informants understood by the term integration. For them, integration mainly entailed adapting to a new culture, learning the local language and getting to know the culture of the society in which they have been granted asylum. Some of them did not like the term integration as it constantly reminded them that they were refugees, a status that most of them did not enjoy having, and an identity they mostly did not want to accept. Instead, they wanted to be regarded as human beings, and not as a special category of asylum seekers or asylees. One informant phrased it in this way:

I want to be regarded as any other Croatian citizen who lives here and goes through the same difficulties as other people. I want to talk about what is going on in Croatia, and not about asylum seeking anymore. 


\section{The rights of refugees in Croatia}

The Act on International and Temporary Protection of the Republic of Croatia (in the following text: the Act) defines the rights and obligations to which persons who are beneficiaries of international protection in Croatia are entitled. According to Article 64 of the Act, refugees (asylees and foreigners under subsidiary protection) have the following rights: residence in the Republic of Croatia, family reunification, accommodation, work, healthcare, education, freedom of religion, free legal assistance, social welfare, assistance with integration into society, ownership of real property pursuant to the 1951 Convention, and acquisition of Croatian citizenship pursuant to the regulations governing the acquisition of citizenship. Their obligations (according to the same article of the Act) are: to respect the Constitution, laws and other regulations of the Republic of Croatia; to register their place of residence within 15 days from notification of the decision approving international protection; to have their residence permit on their person and allow persons authorized by law to examine it; to attend a course in Croatian language, history and culture.

Of the mentioned rights, it is important to clarify that the right to accommodation involves the right to a paid apartment, in cases where the refugee does not possess sufficient financial resources to cover the costs of accommodation by him- or herself. The Croatian state pays the rental costs of the apartment for a period of two years from the date the person receives the decision granting him or her international protection.

Another right - assistance with integration into society - is regulated by Article 76 of the Act. It covers:

1. drawing up a plan for the integration of asylees or foreigners under subsidiary protection in view of their individual needs, knowledge, abilities and skills;

2. providing assistance to asylees or foreigners under subsidiary protection for the implementation of the plan drawn up;

3. supervising the implementation of the plan.

The obligation to attend a course in Croatian language, history and culture is defined by Article 74 of the Act, which stipulates that "asylees and foreigners under subsidiary protection are obliged to attend a course in the Croatian language, history and culture, for the purpose of integration into Croatian society". In the case of a failure to fulfil this obligation, this article also stipulates that "the asylee or foreigner under subsidiary protection shall repay the costs of the course to the Ministry responsible for education". Furthermore, the same article defines the Ministry of the Interior as being in charge of conducting the activities described as "assistance for integration into society”. In an interview I held with a representative of that Ministry, I found out that the mentioned "integration plan" was an internal document that the Ministry did not share with refugees, a kind of internal follow-up of the progress that each refugee has made in exercising his or her rights and therefore progress regarding his or her integration into Croatian society. Another clarification that I required in order 
to understand the functioning of the Act concerned the question of paying a penalty if a refugee does not comply with the obligation to attend the language course. The answer that I got from the Ministry was that this provision of the Act was not implemented as a mechanism that would enable its implementation was not in place. Details regarding other rights will be presented in the next section, through the ethnographic material on how individuals exercise them.

\section{Ethnographies of exercising refugees' rights in Croatia}

The first right that refugees in Croatia have - residence in the Republic of Croatia - is exercised smoothly: a few days after a person receives the decision granting him or her international protection, a clerk from the Ministry of the Interior accompanies him or her to the police station where they issue him or her with a residence permit. In the case where a refugee has been granted asylum, that permit is issued for a duration of five years, and in the case where (s)he has been granted subsidiary protection, the validity of the residence permit is three years. In both cases these initial durations may be extended. Those who are granted asylum can also apply for a passport (issued for a period of five years), while those who receive subsidiary protection can apply for a special travel document (issued for a period of three years). None of the informants mentioned any problem in acquiring the right of residence.

The first person I met during the period of my research, who I will refer to as Informant $A,{ }^{6}$ gained asylum in 2014 . He told me that gaining asylum in Croatia was worse than being an asylum seeker, due to the fact that people only receive $800 \mathrm{HRK}^{7}$ per month once they become beneficiaries of international protection, and are given accommodation in a paid apartment, and are registered as unemployed by the Croatian Employment Service. When they are asylum seekers, they receive $100 \mathrm{HRK}$ per month, but also three meals per day in the reception centre for asylum seekers in which they are accommodated. After Informant A gained asylum, he stayed in the reception centre for asylum seekers, while waiting a further eight months before getting an apartment paid for by the government, as they told him that there was a lack of such apartments available. During this period of waiting for an apartment, he had no right to receive the social financial assistance of 800 HRK. Hence, waiting to attain the right to accommodation in an apartment whose rent would be paid for by the state entailed the impossibility of exercising his right to social welfare. Contrary to Ager and Strang's argument (2004), in Croatia there is a hierarchy of importance of certain domains of integration, and there is a conditionality between these domains: the right to accommodation in a rented apartment needs to be exercised prior to the right to social welfare.

\footnotetext{
${ }^{6}$ Informants have been named Informant A, B, C, etc. (following the order of their appearance in this text) as some of them refused to be named by pseudonyms.

${ }^{7}$ Approximately 105 EUR.
} 
Once Informant A moved into the apartment rented by the state, he had to register as an unemployed person at the Croatian Employment Service (CES) in order to be able to register at the Centre for Social Welfare and to start receiving the mentioned monthly financial assistance. In the CES, they told him that he needed to inform them every month about his unemployment status, but he did not take that seriously. He said that he was thinking that they were not strict in applying that rule, as beforehand the administration gave him an impression of being "relaxed" while he was waiting for the rented apartment: they promised him every month that he would receive it, but that promise was actualized only after eight months. However, his being late with the monthly registration at the CES resulted in his withdrawal from the unemployment register, which resulted in his withdrawal from the register of persons who have a right to social welfare. Therefore, his first few months of integration into Croatian society were months of not only (mis) understanding the functioning of the Croatian administration, but also of struggling for existence. He often needed to borrow money or food from friends.

This first period of his integration into Croatian society was also marked by different encounters with that same society, and in that regard, he told me this:

If you tell people that you are an asylum seeker or refugee, they do not want to communicate with you. If you tell them you are a refugee, they do not even want to shake hands with you.

Therefore, he said, refugees in Croatia sometimes do not want to "discover their identity, their origin". However, he also met people who became his good friends, and he even said: "if you do not have friends, you can die here". Approximately one year after having been granted asylum in Croatia he was called on to attend a Croatian language course. He had already started to learn Croatian somewhat earlier, with volunteers from a non-governmental organization. He was not satisfied with learning Croatian in that way, as the volunteers were not Croatian language professors. When he started to attend the Croatian course organized by the state, he had professors who did not speak English and mutual understanding was therefore not easy. Sometimes the professors would ask him and the other refugees on the course why they were not concentrating on the course. To such comments they would reply with these words: "We have nothing to eat, and you are talking about the language?" This statement and similar ones I encountered during my research led me to conclude that, in addition to the dimensions that the aforementioned scholars (Esser 2001 and Heckmann and Schnapper 2003 op. cit. Penninx and Garcés-Mascareñas 2016; Penninx and Garcés-Mascareñas 2016) referred to when discussing integration, in Croatia we can speak of one further dimension: an existential dimension. Namely, the first issue a person who receives international protection in Croatia encounters is the question of how to cover his or her basic living costs.

My other informants had similar experiences in Croatia. Informant B and Informant $\mathrm{C}$ were both granted asylum during approximately the same period, in summer 2015. For them both, the most unfunctional area of rights they should have had ac- 
cess to (and which was actually, according to Croatian law, an obligation) concerned organized Croatian language courses. Both followed the same Croatian language course that lasted for only 70 hours and they were expecting a follow-up course to occur. They received phone calls about the next course, but when they came to the language school in which the course was organized, they were told that they could not attend it, as it was not a follow-up course, but a beginner course organized for "new" asylees. They were both extremely disappointed as they wanted to learn the Croatian language and the 70-hour long beginner course they had completed was far from enough. As Informant B pointed out, he had "a wish, a need and a thirst" for learning the Croatian language. They were never called again for a further course and Informant $C$ doubted that he would reply to such a call, as he was very angry regarding their behaviour towards them, as they wasted their time: by first informing them to come to the course and then, when they came, telling them that they could not attend it. Informant $B$ had even made an agreement with the company he worked for about his work shifts - an agreement that would allow him to attend the language course, and then he found that the course was not for him, but for "new" asylees. He commented that there was a kind of discrimination among asylees ("old" and "new" ones), which was not fair. This issue of organizing only one, basic Croatian language course, with a duration of 70 hours, was raised by all my informants. They consider the Croatian language to be difficult, and they also knew that, without knowledge of the local language, their chances of finding a job - where they could demonstrate all their knowledge and skills - was tiny. In comparison to this 70-hour Croatian language course, the Netherlands offered 600 hours of integration programmes to refugees, the majority of these hours consisting of the language course (cf. De Vroome and Van Tubergen 2010), while Norway offered an initial 300 hours of language tuition, and the municipalities were obliged to offer up to 2,700 additional hours in their integration programme (including language tuition) for those who had a need for further education (cf. Valenta and Bunar 2010).

Regarding the right to accommodation, which consists of benefiting from an accommodation facility (apartment) paid for by the state for a period of two years from the date the person receives the decision granting him or her international protection, there were some problems as regards its implementation. Namely, although the informants were accommodated in a reception centre for asylum seekers while waiting to be assigned an apartment somewhere in the city of Zagreb, for some of them, this period of waiting for an apartment took too long, up to eight months (as the case of Informant A has already shown). The informants considered the time spent in the reception centre after having been granted asylum to be an unnecessary burden setting back the beginning of their integration into Croatian society. Informant $C$ received the state-paid apartment one month after having been granted asylum, while Informant B received it four months after asylum was granted to him. He actually found the apartment on his own, with the assistance of local friends, as the accommodation they first offered him was some $30 \mathrm{~km}$ away from Zagreb, and he would have had to further wait for another apartment. Informant $\mathrm{D}$ received an 
apartment relatively quickly, around 20 days after he was granted asylum. He said he went to the Centre for Social Welfare and kindly asked them to quickly find him an apartment, as he "hated Porin" (i.e. the Reception Centre for Asylum Seekers ${ }^{8}$ ) and hence, as soon as they offered him a first apartment, he accepted it and signed the rental contract without even seeing what the apartment looked like, thinking: "if I get a place where I can sleep and a place where I can cook something for myself, that is enough for me". Informants $\mathrm{E}$ and $\mathrm{F}$ (a married couple) first entered the state-funded apartment one month after having been granted asylum, although they found it immediately after receiving asylum (a volunteer who worked with an NGO (non-governmental organization) offered them her apartment for rent). In other words, once the apartment had been found, administrative procedures relating to the apartment's rental lasted approximately one month.

A "hatred" of staying in the reception centre, as one informant described it, resonates with the same line of thinking present in the results of De Vroome and Van Tubergen's research. They found:

that a prolonged stay in a reception centre reduces refugees' odds of employment and occupational status, by preventing them from acquiring postmigration education, work experience and language skills, and to a lesser extent by preventing them from acquiring (bridging) social contacts and by causing health problems. (De Vroome and Van Tubergen 2010:398)

All informants went regularly, once a month, to register with the CES before finding a job. None of them found the job through the CES but through friends, acquaintances or non-governmental organizations. This confirms that social bridges (Ager and Strang 2004) that refugees build with people in the host society occupy a high position in the hierarchy of domains of importance for integration. They are important as they connect refugees with the workplace, and the fact that they work (or not) influences the extent to which they are satisfied with their life in Croatia as the host society (the identificational dimension of integration, cf. Esser 2001 and Heckmann and Schnapper 2003 op. cit. Penninx and Garcés-Mascareñas 2016). Such an influence was demonstrated by Informant A, for instance, who I followed over my whole research period. His moods, from depressive to happy ones, depended a lot on his activities, and especially on whether he was regularly working or not.

During their first few months of integration, informants were faced with the sluggishness of the Croatian administration, which Informant A described as "very lazy", lazier than in his home country which he already considered to be very bad. One example he gave was that: "If you need one signature in Croatia, you will wait two or three months for it." Almost all informants had to wait two or three months before they accessed the social welfare benefits they were entitled to. The administration

\footnotetext{
${ }^{8}$ Porin is the informal name of the Reception Centre for Asylum Seekers in Zagreb, as prior to its use as a Reception Centre, the building was used as a hotel whose name was "Porin". In fact, signs pointing in the direction of the three star Hotel Porin were still present in some parts of the city of Zagreb in 2017, while the building ceased to function as a hotel in 2011, when it came to accommodate the Reception Centre for Asylum Seekers.
} 
responsible for these services did not even give them accurate information on the access to all the benefits they have, such as one-time-only financial assistance available before and separately from the monthly social assistance. Informant D explained that he was waiting for more than two months before he started to receive the social assistance of $800 \mathrm{HRK}$ per month that he was entitled to, although he was told by the administration that he would receive it in two weeks or a month. He commented that the administration should know and do its job, explaining it further in this way:

The administration should know that the guy who is here has no mother, father, sister, brother; he is alone, he has no family here. So, if you are a social welfare institution doing that kind of work, one should think about that... at least I think so. If I work in a social welfare office and if somebody who came from abroad comes to me, who I know has no job, does not speak the language, and he is here, needs to eat, sleep... and he brought me a whole dossier in order to get financial assistance based on social care, I would not waste his time for two or three months. For me, it is not human.

But he also added this:

That is the administration here, you are Croatian, you know it. This is what I often tell people when they are asking me such questions: you are Croatian, you grew up here, you know how the Croatian administration is. So, it is how it is.

This was an important moment which I found my research brought to the surface: it shows how when studying "others" we can learn or be reminded about ourselves, and it also emphasizes the major intellectual contribution of modern anthropology to scholarship, which is, according to Marcus and Fischer (2003: 35-36), the ethnographic research process and its two main justifications: the capturing of cultural diversity, and cultural critiques of ourselves.

The Croatian administration was sometimes not informed about the rights that refugees have in Croatia. One example was given by Informant B who encountered problems when travelling by plane from Zagreb to Paris, France. He showed his refugee passport at the Croatian airport border control. Despite it having been issued by the Croatian Ministry of the Interior, the Croatian police officer, according to him, did not recognize that kind of passport. When he showed the officer his Croatian passport with a different (red) colour to the standard (blue) Croatian passport, and with the inscription "Geneva Convention 1951" on its cover page, the policewoman at the border looked at that passport, made a few phone calls and held him at the counter. He commented on it with these words:

I am a Croatian asylee. Croatia has granted me protection. So, I am an asylee in Croatia and for five years I have full rights to everything. I can travel outside the country and come back. They saw on my plane ticket that I was travelling outside of Croatia for five days.

Despite this, he was detained at the passport control counter. However, he added that he did not blame them: "maybe they saw an asylee passport then for the first 
time. Maybe they think that only Croatians have a right to a Croatian passport." Informant B was also faced with the same ignorance of the asylees' rights when he tried to open a bank account at an office of a bank that is otherwise a member of a large European banking group. He explained:

What was a bit weird was the fact that people who worked in the bank did not know... Later on, I realized that for bank clerks who work here, at Črnomerec, ${ }^{9}$ it was the first time they had seen a black guy who had come to open a bank account, as an asylee. They had doubts. There were too many procedures: "No... we have to call our boss, we have to call our lawyer..." It surprised me because an asylee is a person who has all the rights, except perhaps the right to vote in elections. But I have all the rights... They told me: we have to call the bank's lawyer in order to check it, and I told them: alright, do not hurry, take your time...

This quotation, which ended on a sarcastic note, demonstrates once again the patience that refugees need to have while exercising their rights in Croatia, not only with the various state institutions, but also with private legal entities. Informant B was called two or three days later by the bank clerk who finally informed him that he could open a bank account. The informant added that he could understand such behaviour as different people did not know about refugees as beneficiaries of international protection, and that such a person, refugee, "who is protected, has become, in a way, a citizen of that country".

Informants $\mathrm{B}$ and $\mathrm{C}$ encountered problems with accessing their right to healthcare too, a right that should be equal to the healthcare right other citizens of Croatia have. Informant $\mathrm{G}$ even told me that he did not have a right to healthcare. Other informants knew about the problems with exercising that right, adding that they were happy as they did not need to go to the doctor. Informants B and C also did not have considerable problems with their health but they nevertheless went to hospitals for health reasons on occasion and were then confronted with administrative problems, as they did not have the same health card as other citizens and the public health IT systems did not recognize them. Informant B described his visit to the doctor with these words:

To someone who is in pain, who is very ill and urgently needs medical care, you say to come next week? So, the person may die, and you do not care about foreigners?... First and foremost, it is necessary to take care of sick persons, and procedures should come later... That doctor did not care about us; somebody could die because of too many procedures.

He added that he did not believe that it was possible that the doctor would behave in such a way with a Croatian patient, adding that, "if this were the case, you would start killing people”.

\footnotetext{
${ }^{9}$ Črnomerec is a neighbourhood in the city of Zagreb.
} 
The problem of not being recognized by public health institutions would be solved by my informants once they had found a job and then, as employees, they would get health insurance cards that are recognized by the IT systems of hospitals and other related institutions, including pharmacies.

In the area of education, refugees have the right to attend the state-funded secondary and tertiary education programmes, a right equal to that of Croatian citizens. However, similarly to the health system, there is an IT-based barrier impeding access to the state-funded universities. Namely, the universities' IT system recognizes two categories of enrolled students: Croatian citizens (whose studies are subsidised) and third-country nationals (whose studies are not subsidised by the Croatian state). One problem concerns the recognition of previously acquired qualifications, despite the provisions of Article 70 of the Act on International and Temporary Protection that should facilitate the process of the recognition of refugees' foreign qualifications. Informant B summarized the problem of attending Croatian universities in the following way:

But I am not sure if persons who got asylum before me attend a university here. No, nobody. There are too many procedures. They tell us that we have that right, but there are too many procedures around it, unnecessary blockades. I do not know any asylee who studies here with state support. It means that I cannot go that way. I could try it, but I would be wasting my time for nothing. Because of unnecessary procedures: go here and there... I would become tired, for nothing.

Informant $\mathrm{D}$ told me that he would like to enrol at the university, but before doing so, he said he needed to first learn the Croatian language well. Informant $\mathrm{E}$ graduated in law in his home country, but he was not even considering entering into the process of nostrifikacija (the process of having his diploma recognized) of his diploma in Croatia as for that process he would need to first complete two years as a regular student at a law faculty. He did not have time for this as he needed to work and take care of his five person family.

However, Informant B finished the training programme to become a forklift driver, Informant $\mathrm{C}$ finished a training programme for chefs, and Informant $\mathrm{D}$ completed the programme for being a car painter. Scholarships for these programmes were financed by the Croatian Red Cross, through a project this organization was implementing. These training programmes helped Informant $C$ to get the necessary qualification for the job he was already doing (a chef), and helped Informant $\mathrm{B}$ to get a job (as a forklift driver). Informant $D$, who attended the programme for car painters, did not succeed in getting a job in the profession for which he trained. Informant B said that they could choose among several training programmes that were offered to them, and he chose and finished the forklift driver course, thinking that such a technical course would enable him to find a job, "instead of pursuing things that could become complicated and spending five years somewhere for nothing. I call it a shortcut", he added. His strategy turned out to be a good one, as two months after 
he finished the course he found the forklift driver job in an enterprise that employed several asylum seekers. He found that job through a friend, an asylee, who received the offer through the Rehabilitation Centre for Stress and Trauma (RCT) Zagreb, an NGO implementing a project that included job matchmaking services for asylees. However, he said that he got that job as a woman from the enterprise recognized him as a djembe player. She first saw him on the television and then met him in the school that her daughter attended. He was a member of the Society of Africans in Croatia (abbreviated in Croatian to: DAH) and he regularly participated at DAH's presentations of Africa in schools and kindergartens throughout Croatia, where he played the djembe or told African fairy tales to children. Here, once again, building social bridges (Ager and Strang 2004) with members of the host communities showed itself to be of the utmost importance for the integration of refugees in Croatia. Social bridges in this case were bridges that connected a refugee with a job. This was also the case with most of the other informants, as they found work through their connections with people from the host society. Non-governmental organizations proved to be useful in that process as intermediaries for finding a job (organizations such as RCT Zagreb, Are You Syrious?, the Centre for Peace Studies, and the Croatian Red Cross) or reference points that recommend refugees for certain jobs (DAH). Nongovernmental organizations also assisted in the accommodation of refugees: during the research period, the Jesuit Refugee Service (JRS) had an informal agreement with state institutions for assisting them in finding apartments for refugees, while the Red Cross provided the refugees with some groceries once they had moved in the apartments that the state rented for them. However, some informants were sceptical towards the usefulness of the NGOs, considering them as just "eating money and doing nothing", as one informant put it, or emphasizing the problem of a lack of paid staff who work in such organizations. On many occasions, refugees had to rely on unpaid volunteers, which equalled a dependence on someone's free time and a lack of a service provided by an NGO when it was really needed. Informants D and E said that many organizations claimed to be helping the refugees in exercising their rights, "but how are they doing it? You visit them and they tell you: you need to go there-and-there. Sometimes they help you, but one person ${ }^{10}$ is not enough."

When further discussing the right to work, the research showed that besides the question of getting a job when refugees do not speak the Croatian language and the fact that their previous educational attainment was mostly not recognized in Croatia, finding a job that would be paid well enough to cover their basic needs - including the renting of an apartment after the two years of their right to state-paid accommodation expired - was clearly an important issue for them. This existential dimension to integration into Croatian society is summarized in the thoughts of Informant $\mathrm{G}$ who explained that in Croatia there was no job or there were jobs for a salary of 2,000 or 3,000 HRK, which was insufficient for a person to live off, as the cost of rent for a small apartment in Zagreb was 2,000 HRK.

\footnotetext{
${ }^{10}$ Meaning: one person who is (usually) employed in such an organization to work directly with refugees.
} 
As regards the right to freedom of religion, my informants did not mention any problems in exercising that right. Only two informants expressed their doubts over whether a woman wearing a hijab would be accepted by any employer. The religion of Islam was also connected with a restriction affecting what jobs one informant could accept. Namely, he said that he could not work in a restaurant that prepares and serves pork, nor in a bar or restaurant serving alcoholic drinks. As for family reunification, only a few informants were interested in exercising that right, but one was not sure if that were possible, while another was informed - by the non-governmental organizations - that it was not possible for him to exercise that right and that he also had no financial means to do it. As for other rights that they were entitled to by law, they either did not (yet) have a need to exercise them (free legal assistance, ownership of real property, acquisition of Croatian citizenship) or they were not aware of these rights, such as the right surrounding assistance for integration into society as explained in the previous section.

\section{Interpreting the research in light of Foucault's thoughts on biopolitics}

Michel Foucault (2007: 16) defines bio-power as

the set of mechanisms through which the basic biological features of the human species became the object of a political strategy, of a general strategy of power, or, in other words, how, starting from the eighteenth century, modern western societies took on board the fundamental biological fact that human beings are a species.

Furthermore, Foucault equates bio-power with biopolitics (Foucault 2004: 23). ${ }^{11}$ His analysis of méchanismes de pouvoir (power mechanisms) distinguishes between three mechanisms: the legal or juridical mechanism, the disciplinary mechanism, and the dispositif de sécurité or apparatus of security (Foucault 2004, 2007). The latter mechanism is the focus of his study on security, territory and population, which I find relevant to the above presented research into refugees and their rights in Croatia after having received international protection. The security, Foucault argues, is exercised over a whole population and, as an example, he analyses dispositifs de sécurité through the problem of the event and relationship of the government to the event, using an example of scarcity (la disette). From that example he demonstrates that there are two levels of phenomena: the first is the level of the population, the only level at which it is pertinent for the government to act. The second level is the level of the multiplicity of individuals who are relevant for the economic and political action

\footnotetext{
${ }^{11}$ This part of the paper is based on both Foucault's original version (2004) and the version translated into English (2007) of his courses on security, territory and population. These courses were held at the Collège de France in 1977 and 1978.
} 
of the government, yet only to the extent that it is valid for the realization of goals aimed at being attained at the level of the population.

The final objective is the population. The population is pertinent as the objective, and individuals, the series of individuals, are no longer pertinent as the objective, but simply as the instrument, relay, or condition for obtaining something at the level of the population. (Foucault 2007: 65)

Between these two levels there is a césure fondamentale or fundamental caesura, which is a break between the level of the population, that is pertinent, and the level of the multiplicity of individuals that is not pertinent or that is simply an instrumental level. This césure fondamentale exists within the system of knowledge-power, within the system of technological and economic management.

In light of Foucault's thoughts as presented here, this paper's research deals with the level of individuals, who are part of the second, non-pertinent level of the dispositif de sécurité and, as such, it is not so important for government to act, when compared to the first level, the level of the population, which is the level of the legal act (Act on International and Temporary Protection of the Republic of Croatia), which the refugees rely on when looking for the rights they have as persons who are entitled to international protection in Croatia. The fact that the legal code that grants them this protection has not been applied in certain aspects and cases, can be qualified as a césure fondamentale. Namely, they, as individuals, are not relevant or pertinent to the economic and political goals of the government and hence a break or gap occurs between the law that exists on paper (as laws are tools for the regulation of certain issues at the level of the population) and the reality of not respecting the law at the level of the multiplicity of individuals.

On the other hand, in his text on governmentality, Foucault describes another point, also of relevance to the presented research:

$[\ldots]$ the state, no more probably today than at any other time in its history, does not have this unity, this individuality, this rigorous functionality, not, to speak frankly, this importance; maybe, after all, the state is no more than a composite reality and a mythicized abstraction, whose importance is a lot more limited than many of us think. Maybe what is really important for our modernity - that is, for our present - is not so much the étatisation of society, as the "governmentalization" of the state. (Foucault 1991: 103)

Bearing in mind that by governmentality Foucault referred to "the ensemble formed by the institutions, procedures, analyses and reflections, the calculations and tactics that allow the exercising of this very specific albeit complex form of power, which has as its target population, as its principal form of knowledge political economy, and as its essential technical means, apparatuses of security" (ibid.: 102), I would conclude that the research presented in this paper problematizes not only the position of individual refugees in Croatian society, but also questions the position of every individual citizen in contemporary European society, where the population, 
as an abstract concept, remains as pertinent, while individuals become ever more non-pertinent subjects of governmental actions.

\section{Conclusion}

The results of the qualitative research that I conducted between February 2015 and September 2017 have shown that the integration of refugees into Croatian society is a dynamic process that depends, on the one hand, on the quality of the institutional infrastructure that Croatian society provides to refugees, as beneficiaries of international protection and, on the other hand, on the individuals who received this protection. The institutional infrastructure of integration consists of legislation that grants rights to refugees and institutions that implement legislation. Refugees who have received international protection in Croatia are entitled to the same rights as Croatian citizens, except for the right to vote in national or local elections. This research has shown that the main Croatian legislative act that grants rights to refugees and that also refers to their integration in Croatian society, the Act on International and Temporary Protection (Zakon o međunarodnoj i privremenoj zaštiti), was only partially implemented.

Its implementation was the most problematic in the areas that refugees consider as essential and as being top priority for their integration: the provision of statesupported Croatian language and culture courses. The courses on Croatian language, history and culture, whose attendance for beneficiaries of international protection is even a legal obligation, have not been organized regularly, and even when they were on rare occasions organized, the refugees were provided with an insufficient 70 hours. Other areas of integration in which deficiencies in the implementation of the law have been demonstrated include access to healthcare and access to the education system. Legislation that exists "on paper" but is actually not implemented sheds light not only on the life of refugees in Croatia during the researched period, but also on the functioning of Croatian institutions. In this researched case, Croatian legislation was not implemented fully, while responsibility on the part of institutions in some cases almost did not exist. Inefficient bureaucracy and administrative barriers encountered by my informants in Croatia were not so easy for them to understand without the help of their friends - members of the host society. But once understood, they brought one informant to the following conclusion: "That is the administration here, you are Croatian, you know it."

The research also pointed out that the public administration was sometimes not sensible nor even informed about the rights of the persons who were beneficiaries of international protection in Croatia: to some healthcare workers, the procedures were more important than healing a patient, while a police officer at the international border crossing of Croatia did not recognize a refugee passport, thinking perhaps that "only Croatians have a right to a Croatian passport". Both examples point out tendencies that Herzfeld (1992: 108) summarized as follows: 
Bureaucrats, who hold the power to admit citizens into the national image, also serve as godfathers and patrons who retranslate the homogenous state back into social terms, and who control the definition of what is or is not the correct form (in both the abstract and bureaucratic senses of that word!).

Non-governmental organizations and individuals, from or outside these organizations, were most helpful in assisting the refugees in exercising their rights. They were also helpful in serving as job matchmakers. As regards the right to work, this research conducted over a period of two and a half years has demonstrated that almost all informants found a job, but for none of them did the state-funded Centre for Employment Service serve as an intermediator in the process of finding the job. Instead, the job intermediators were non-governmental organizations or local friends. Also, for most of the informants, their previously acquired qualifications did not count, and only one informant got a job for which he was qualified before arriving in Croatia (truck driver) while another got the job in the same profession (lawyer's office), but a lower-ranked position (as an office assistant, not as a lawyer - the qualification and the work he did in his home country). This confirms what De Vroome and Van Tubergen (2010: 396) point out - that it is more likely that the education of a refugee acquired in the host country positively influences their finding employment, but that both education acquired in the host country and education acquired abroad contribute to a refugee's economic integration.

Some informants, referring to their experiences in other countries, have suggested that there should be more organizations that help refugees and asylum seekers in Croatia, and that they should employ more people instead of relying on volunteers, who are usually engaged by these organizations in the work of assisting the integration of refugees.

Of the many dimensions to integration to which scholars of migration refer in their work (cf. Esser 2001 and Heckmann and Schnapper 2003 op. cit. Penninx and Garcés-Mascareñas 2016; Penninx and Garcés-Mascareñas 2016), the interaction dimension showed to be the most important for refugees who are supposed to integrate into Croatian society: interaction here refers to their connections with local people and the new friends they make in the host society (building social bridges, cf. Ager and Strang 2004); friends who help them navigate the many areas that integration involves, first and foremost in exercising the rights they have. Besides this, this research acknowledges the importance of the existential dimension of integration, that other scholars do not recognize as such, probably as they have mostly conducted their research in wealthier countries in Europe or in other parts of the world. The existential dimension of integration into Croatian society refers to learning the Croatian language and to the possibility of getting a job able to cover the core needs and basic costs of living that a refugee, a beneficiary of international protection, encounters in Croatia once the state assistance in covering the costs of a rented apartment expires, two years after international protection has been granted to a refugee.

To sum up, this research has shown that in Croatia the foundation of the integration policy (for refugee rights) to which governments are accountable (cf. Ager and 
Strang 2008: 175) is porous, while the institutions in charge of supporting that foundation, or - better said - the people working in these institutions, often do not seem to be accountable as far as the implementation of certain refugee rights is concerned. This foundation is, however very important for other areas of integration. For instance, access to higher education is important in order to have an opportunity to get a better job, which is a step beyond simply having the right to work. In addition, the fact that a person has a right but cannot actually exercise it inevitably leads that person to feel as (one more) kind of noncitizen or denizen (cf. Agamben 1995; Hammer op. cit. Agamben 1995: 117-118). On the other hand, when confronted with Foucault's analysis of méchanismes de pouvoir and the dispositif de sécurité, the conclusion is as follows: refugees, who are represented more at the level of multiplicity of individuals than at the level of the population, are persons of no prime interest for the government to act as far as ensuring the exercising of their rights - given to them at the level of state - is concerned. Furthermore, the state might not have unity, individuality, rigorous functionality, not even importance, as Foucault (1991: 103) observed, in dealing with such matters. However, the government has these qualities. As a reply to this, the refugees have only one solution remaining: to keep building social bridges with the host society, whose representatives should then bring the issue of human rights up to the level pertinent for the government to act: the level of the population.

\section{REFERENCES}

Abu-Lughod, Lila. 1991. "Writing Against Culture”. In Recapturing Anthropology. Working in the Present. Richard G. Fox, ed. New York: School of American Research Press, 137-162.

Agamben, Giorgio. 1995. "We Refugees”. Symposium. A Quarterly Journal in Modern Literatures 49/2: 114-119. https://doi.org/10.1080/00397709.1995.10733798

Ager, Alastair and Alison Strang. 2004. Indicators of Integration. Final Report. London: Home Office.

Ager, Alastair and Alison Strang. 2008. "Understanding Integration. A Conceptual Framework". Journal of Refugee Studies 21/2: 166-191. https://doi.org/10.1093/jrs/fen016

Baričević, Vedrana. 2014. "Europeizacija azilnih politika i izbjeglička prava. Razvoj hrvatskog sustava azila i zaštita izbjeglica u Hrvatskoj”. In Stranci pred vratima Europe. Anđelko Milardović, ed. Zagreb: Pan liber, Institut za europske i globalizacijske studije, 111-136.

Castles, Stephen, Maja Korac, Ellie Vasta and Steven Vertovec. 2002. Integration. Mapping the Field. Home Office Online Report 28/03. London: Research Development and Statistics Directorate, Home Office.

De Vroome, Thomas and Frank van Tubergen. 2010. “The Employment Experience of Refugees in the Netherlands”. The International Migration Review 44/2: 367-403. https://doi.org/10.1111/j.1747-7379.2010.00810.x

Emerson, Robert M., Rachel I. Fretz and Linda L. Shaw. 1995. Writing Ethnographic Fieldnotes. Chicago, London: University of Chicago Press. https://doi.org/10.7208/chicago/9780226206851.001.0001

Foucault, Michel. 1991. “Governmentality”. In The Foucault Effect. Graham Burchell, Colin Gordon and Peter Miller, eds. Chicago: The University of Chicago Press, 87-104.

Foucault, Michel. 2004. Sécurité, territoire, population. Paris: Gallimard / Seuil.

Foucault, Michel. 2007. Security, Territory, Population. New York: Palgrave.

Herzfeld, Michael. 1992. The Social Production of Indifference. Exploring the Symbolic Roots of Western Bureaucracy. Chicago, London: The University of Chicago Press.

Jurković, Rahela. 2018. Integracija osoba pod međunarodnom zaštitom u hrvatsko društvo. Doktorska disertacija. Zagreb: Filozofski fakultet Sveučilišta u Zagrebu.

Lalić Novak, Goranka. 2013. “Sustav azila u Republici Hrvatskoj. Dosadašnji razvoj i moguće perspektive”. In Prvih deset godina razvoja sustava azila u Hrvatskoj (s osvrtom na sustave azila u regiji). Drago Župarić-Iljić, ed. Zagreb: Institut za migracije i narodnosti, Centar za mirovne studije, Kuća ljudskih prava, 15-32. 
Kirkwood, Steve, Andy McKinlay and Chris McVitti. 2014. “'He’s a Cracking Wee Geezer from Pakistan'. Lay Accounts of Refugee Integration Failure and Success in Scotland”. Journal of Refugee Studies 28/1: 1-20. https:// doi.org/10.1093/jrs/feu003

Malkki, Liisa H. 1996. “Speechless Emissaires. Refugees, Humanitarianism, and Dehistoricization”. Cultural Anthropology 11/3: 377-404. https://doi.org/10.1525/can.1996.11.3.02a00050

Marcus, George E. and Michael M. J. Fischer. 2003. Antropologija kao kritika kulture. Zagreb: Naklada Breza.

Penninx, Rinus. 2007. "Integration Processes of Migrants. Research Findings and Policy Challenges”. Migracijske $i$ etničke teme 23/1-2: 7-32.

Penninx, Rinus and Blanca Garcés-Mascareñas. 2016. "The Concept of Integration as an Analytical Tool and as a Policy Concept”. In Integration Processes and Policies in Europe. Contexts, Levels and Actors. Blanca GarcésMascareñas and Rinus Penninx, eds. Cham: Springer, 11-30. https://doi.org/10.1007/978-3-319-21674-4_2

Pittaway, Eileen, Chrisanta Muli and Sarah Shteir. 2009. “'I Have a Voice-Hear Me!' Findings of an Australian Study Examining the Resettlement and Integration Experience of Refugees and Migrants from the Horn of Africa in Australia”. Refuge 26: 133-146.

Potkonjak, Sanja. 2014. Teren za etnologe početnike. Zagreb: Hrvatsko etnološko društvo, Filozofski fakultet Sveučilišta u Zagrebu.

Smith, Ria. 2015. “'Trying to Make South Africa My Home'. Integration into the Host Society and the Well-being of Refugee Families". Journal of Comparative Family Studies 46/1: 39-55.

Valenta, Marko and Nihad Bunar. 2010. "State Assisted Integration. Refugee Integration Policies in Scandinavian Welfare States: The Swedish and Norwegian Experience”. Journal of Refugee Studies 23/4: 463-483. https:// doi.org/10.1093/jrs/feq028

Zakon o međunarodnoj $i$ privremenoj zaštiti. NN 70/15. https://narodne-novine.nn.hr/clanci/sluzbeni/2015_06_70_1328.html. NN 127/17. https://narodne-novine.nn.hr/clanci/sluzbeni/2017_12_127 _2880.html. Translation of the Act on International and Temporary Protection, available at: http://www.refworld.org/cgi-bin/texis/vtx/rwmain?page=publisher\&docid=4e8044fd2\&skip=0\&publisher=NATLEGBO D\&querysi=croatia\&searchin=fulltext\&sort=date (accessed 16.3.2018).

Župarić-Iljić, Drago, ed. 2013. Prvih deset godina razvoja sustava azila u Hrvatskoj (s osvrtom na sustave azila u regiji). Zagreb: Institut za migracije i narodnosti, Centar za mirovne studije, Kuća ljudskih prava.

\section{Integracija izbjeglica u hrvatsko društvo. Etnografije ostvarivanja prava}

Izbjeglice, kao osobe pod međunarodnom zaštitom u Hrvatskoj, stekli su prava čije se ostvarivanje razmatra u ovom radu na temelju kvalitativnog istraživanja provedenog od veljače 2015. do rujna 2017. godine. U radu se propituje kako pojedinci, osobe koje su dobile azil u Hrvatskoj, ostvaruju prava koja im pripadaju. Istraživanje je zasnovano na etnografiji pojedinačnog i uključuje sudioničko promatranje, otvorene i polustrukturirane intervjue s izbjeglicama i predstavnicima institucija i organizacija uključenih u integraciju. Osnovni hrvatski zakonodavni akt koji je bio na snazi u razdoblju provođenja istraživanja provodio se samo djelomično. Njegova je provedba bila najproblematičnija u području koje su izbjeglice smatrali esencijalnim za integraciju: tečajevima hrvatskog jezika koje organizira država. Druga sporna područja ostvarivanja prava bila su pristup zdravstvenoj skrbi i obrazovnom sustavu. U radu se također uspoređuju rezultati dobiveni u istraživanju s rezultatima migrantskih i izbjegličkih studija provedenih u (uglavnom) zapadnoeuropskim zemljama. Osim sličnosti s tim radovima, ovo je istraživanje prepoznalo važnost lokalnog konteksta za integraciju i uvelo novu, egzistencijalnu dimenziju integracije koja se pokazala ključnom za uspješnu integraciju izbjeglica u Hrvatskoj.

Ključne riječi: izbjeglice, međunarodna zaštita, azil, supsidijarna zaštita, integracija 